\title{
Impact of Acute Deltamethrin Poisoning on Rat Adrenal Glands: Biochemical and Pathomorphological Study
}

\author{
Eugene A. Chigrinski, $\mathrm{PhD}^{1 *}$; Taras V. Gerunov, $\mathrm{PhD}^{2}$; \\ Liudmila K. Gerunova, $\mathrm{PhD}$, $\mathrm{ScD}^{2}$; Petr P. Zolin, $\mathrm{PhD}^{1}$ \\ ${ }^{1}$ Omsk State Medical University \\ ${ }^{2}$ Omsk State Agrarian University named after P.A. Stolypin \\ Omsk, the Russian Federation
}

\begin{abstract}
Background: Deltamethrin is known all over the world as an effective preparation for the control of insects. In connection with this, its role as a chemical stressor increases. The aim of the study was to determine the features of the functioning and structure of adrenal glands (AG) after a single administration of synthetic pyrethroid deltamethrin in experimental animals at a dose of $17.4 \mathrm{mg} / \mathrm{kg}(1 / 5 \mathrm{LD} 50)$.

Material and Methods: For the experiment, 88 male Wistar rats with a body weight of $240 \pm 10 \mathrm{~g}$ were divided into 8 groups of 10-12 animals each. Groups 1, 3, 5, and 7 were control groups, which were administered physiological solution intragastrically. The animals in Groups 2, 4, 6, and 8 received a single dose $(17.4 \mathrm{mg} / \mathrm{kg})$ of deltamethrin, which corresponds to $1 / 5 \mathrm{LD} 50$. In the serum of rats, the content of ACTH, progesterone, DHEAS, corticosterone and aldosterone was determined by EIA. Histological preparations of adrenal glands were stained with H\&E, picrofuxin according to Van Gieson, and with Bismarck brown according to Shubich. On frozen sections, lipids were detected by Sudan Black B.

Results: One day after intoxication, we identified an increase in adrenal mass, edema of the parenchyma and blood capillary overflow, and a large number of lipids in corticocytes. In the blood serum, the concentration of ACTH and corticosteroids increased, but their level decreased in the adrenal cortex. After 3 days, the concentration of corticosterone in the blood serum of the experimental animals remained above the control value, but the content of other hormones decreased. At the border of the cortex and the medulla of the adrenal glands, there were mast cells in a state of degranulation; the amount of lipids decreased with time. In the subsequent terms of the study, a decrease in the weight of AG with a decrease in the concentration of hormones in the blood serum and adrenal tissue was detected.

Conclusion: The intoxication of rats with deltamethrin causes morphofunctional changes in AG that characterize the development of the stress response. The hormonal background is not restored within a month, which indicates the possibility of developing post-toxic complications. (International Journal of Biomedicine. 2017;7(3):221-225.)
\end{abstract}

Key Words: pesticides • pyrethroids • deltamethrin • adrenal glands • steroid hormones

\section{Abbreviations}

AG, adrenal glands; ACTH, adrenocorticotropic hormone; BW, body weight; DHEAS, dehydroepiandrosterone sulfate; EIA, enzyme immunoassay; H\&E, hematoxylin and eosin.

\section{Introduction}

Synthetic pyrethroids are drugs of neurotropic action. They disrupt the functioning of the sodium, chloride and calcium

*Corresponding author: Eugene A. Chigrinski, PhD Department of Biochemistry, Omsk State Medical University. Omsk, Russia.E-mail: chigrinski@list.ru channels of neurons. ${ }^{(1)}$ These effects can be accompanied by the development of other undesirable effects that involve the reproductive, ${ }^{(2,3)}$ immune, ${ }^{(4,5)}$ cardiovascular, ${ }^{(6,7)}$ respiratory ${ }^{(8,9)}$ and other systems, and also contribute to a high risk of cancer development. ${ }^{(10)}$ People contact pyrethroids when they are used in industrial activities and households, as well as from consumption of vegetables, fruits and water contaminated with their residues. ${ }^{(11)}$ 
The world market of pyrethroids was estimated at more than 2.5 billion dollars in 2016 (according to Stratistics MRC), and by 2023 will exceed 4 billion dollars. ${ }^{(12)}$ Among pyrethroids, deltamethrin is one of the most popular and widely used insecticides in the world. ${ }^{(13)}$ It is used in agriculture and veterinary medicine for the destruction of pests of plants and ectoparasites of animals. In this connection, there is an increasing interest in studying its toxicity for animals and humans. ${ }^{(14-17)}$ Adrenal glands (AG) play an important role in maintaining homeostasis during the influence of chemical stressors. They participate in the implementation of adaptive mechanisms in the hypothalamic-pituitary-adrenal axis, ${ }^{(18-20)}$ coordinating the work of all organs and systems in a stressful situation.

The aim of the study was to determine the features of the functioning and structure of AG after a single administration of synthetic pyrethroid deltamethrin in experimental animals at a dose of $17.4 \mathrm{mg} / \mathrm{kg}(1 / 5 \mathrm{LD} 50)$.

\section{Material and Methods}

For the experiment, 88 male Wistar rats with a body weight of $240 \pm 10 \mathrm{~g}$ were divided into 8 groups of 10-12 animals each. Groups 1, 3, 5, and 7 were control groups, which were administered physiological solution intragastrically. The animals in Groups 2, 4, 6, and 8 received a single dose (17.4 $\mathrm{mg} / \mathrm{kg}$ ) of deltamethrin, which corresponds to $1 / 5$ LD50. To determine the dynamics of the content of adrenal hormones in the blood and glandular tissue, rats were withdrawn from the experiment step by step: rats in Groups 1 and 2 - one day after the experiment, in Groups 3 and 4 - after 3 days, in Groups 5 and 6 - after seven days, and in Groups 7 and 8 - after 30 days of the deltamethrin administration. In the course of the experiment, the preparative form of deltamethrin was used under the trade name "Butox 50" (Intervet, Netherlands). The study protocol was reviewed and approved by the Ethics Committee of the Omsk State Medical University. All stages of the experiment were carried out in accordance with the requirements of Directive 2010/63/EU of the European Parliament and of the Council of 22 September 2010 on the protection of animals used for scientific purposes.

In the serum of rats, the content of $\mathrm{ACTH}$, progesterone, DHEAS, corticosterone and aldosterone was determined. AG of animals were removed and weighed. The right adrenals were homogenized at $0-2^{\circ} \mathrm{C}$ and the content of steroid hormones was determined in the resulting homogenate. The content of ACTH, progesterone, corticosterone and aldosterone was determined by direct competitive ELISA with the antibodies immobilized on the solid phase. The amount of DHEAS was determined by a "sandwich" solid-phase enzyme immunoassay. For the EIA, the kits of Cusabio Biotech Co. Ltd (China) and DRG International Inc (USA) were used.

The left AG were fixed in a $4 \%$ neutral solution of formaldehyde. Histological preparations were stained with H\&E, picrofuxin according to Van Gieson, and with Bismarck brown according to Shubich. On frozen sections, lipids were detected by Sudan Black B. The study of histological preparations was carried out using the Altami BIO 1 microscope (Altami, Russia).
Statistical analysis was performed using the statistical software «Statistica» (v6.0, StatSoft, USA). The results are presented as $M e$ (median), $Q 1$ (lower quartile), and $Q 3$ (upper quartile). The Mann-Whitney (U Test) was used to compare the differences between the two independent groups. A probability value of $P<0.05$ was considered statistically significant.

\section{Results}

We recorded the change in body weight (BW) of rats as a result of exposure to a toxic dose of deltamethrin. A day after the beginning of the experiment, rats of the Groups 1 and 2 had the same BW. However, on the third day there was a decrease in BW by $3.7 \%$ in animals subjected to intoxication, compared to the corresponding control group (Fig. 1). In subsequent observation periods, the BW of rats subjected to deltamethrin was lower than in control animals. In this case, a change in the weight of AG was noted. Thus, on the third day of the observation, the weight of the AG increased, but on the 30th day it decreased compared to the corresponding control group (Fig. 2). Accordingly, the mass index of AG showed a statistically significant increase on the third day of observation, but had decreased by the 30th day (Fig. 3).

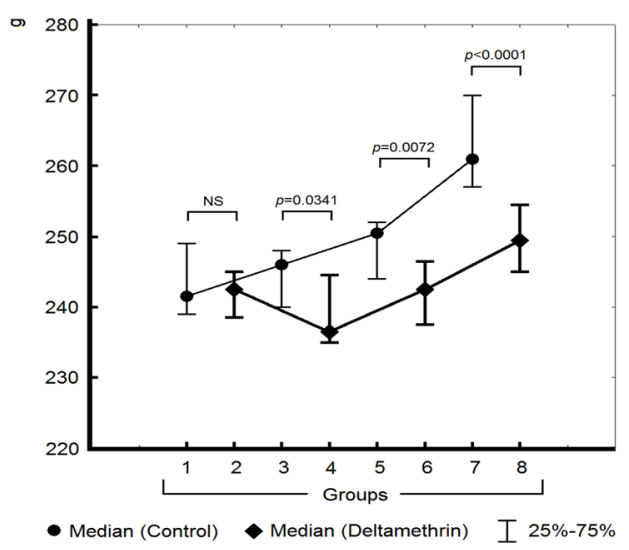

Fig. 1. Changes in $B W$ of rats after single administration of deltamethrin.

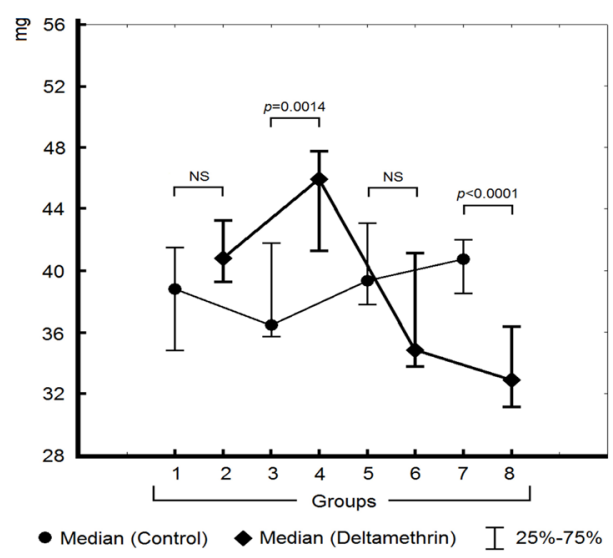

Fig. 2. Changes in adrenal mass in rats subjected to deltamethrin intoxication. 


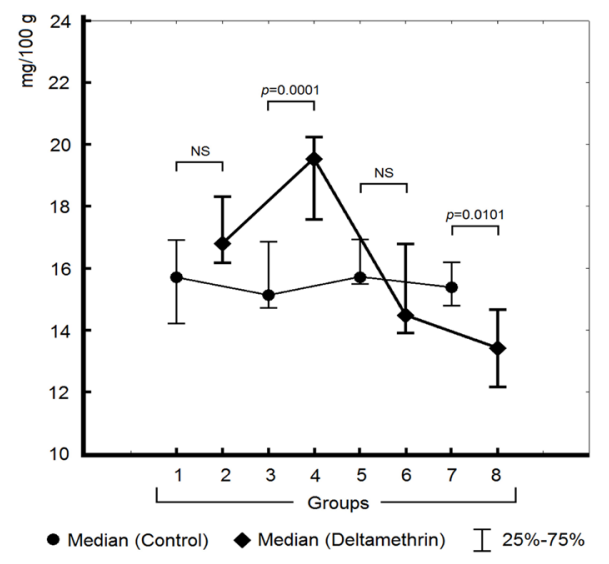

Fig. 3. Mass index of adrenal glands in rats subjected to deltamethrin intoxication.

A single deltamethrin administration at a dose of $1 / 5$ LD50 led to an increase in serum ACTH level after the first day of the experiment. Thus, the content of this hormone in the blood of rats in Group 2 was $78.9 \%$ higher than in the first control group (Fig. 4). However, on the third day of the experiment, we observed a decrease in the ACTH level of rats subjected to deltamethrin intoxication. In later periods of the experiment, there were no statistically significant differences in the content of ACTH in the animals of the experimental and control groups.

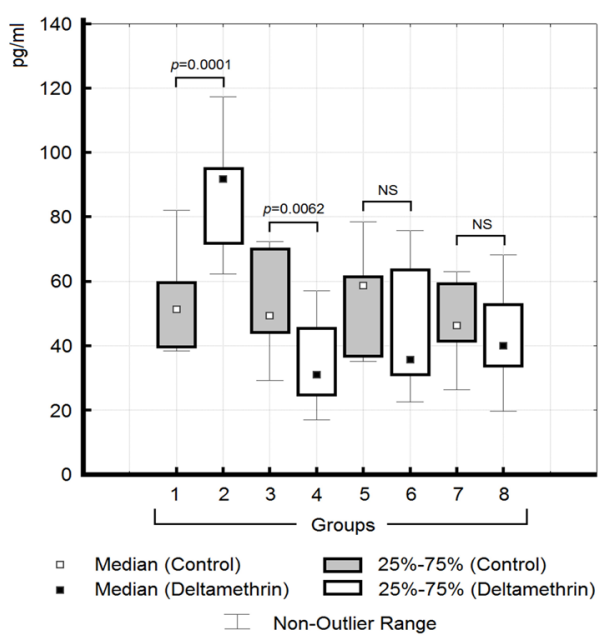

Fig. 4. ACTH level in the blood serum of rats subjected to deltamethrin intoxication.

Intoxication with deltamethrin was accompanied by disruptions in the synthesis of steroid hormones. A decrease in the level of progesterone in the serum was observed on Days 7 and 30 of the experiment (Table 1). In the body of males, this hormone is a precursor in the synthesis of corticosteroids and androgens, ${ }^{(21)}$ so reducing its concentration in adrenal tissue in males is the most dangerous. The DHEAS level in the blood serum of rats characterizes the androgen-synthesizing function of AG. One day after the experiment, there was an increase in the level of this hormone in the blood. The DHEAS level in the serum of the rats of Group 2 was $46.2 \%$ higher than in Group 1 (Table 1). Simultaneously, a decrease in the content of this hormone in the adrenal tissue was found. So, in Group 2, on the first day after deltamethrin introduction, this indicator was $26.2 \%$ below the control level. At other times of observation, there were no statistically significant differences in the DHEAS content in adrenal tissue and in the blood of experimental and control animals.

Despite the restoration of the androgen-synthesizing function of $\mathrm{AG}$ after a single deltamethrin administration, the synthesis of gluco- and mineralocorticoids was disrupted. The first day of the experiment showed an increase in the level of corticosterone and aldosterone in the blood of rats subjected to deltamethrin administration. The serum level of corticosterone and aldosterone in the rats in Group 2 was higher by $30.5 \%$ and $61.2 \%$, respectively, than the control values (Table 1 ). On the third day, the level of corticosterone remained elevated, and the aldosterone content returned to normal value. Seven days after deltamethrin intoxication, the serum level of corticosterone normalized, but the aldosterone level decreased. However, at the final stage of the experiment, on the 30th day, we registered a deficiency of both hormones in the blood of experimental animals. The serum level of corticosterone and aldosterone in the rats of Group 8 was lower by $36.7 \%$ and $43.8 \%$, respectively, in comparison with the corresponding parameters in the corresponding control group (Table 1).

Along with a change in the level of corticosteroids in the blood of rats subjected to acute intoxication with deltamethrin, we found a change in the content of these hormones in adrenal tissue. One day after the experiment, the corticosterone level was significantly reduced, on the third day it returned to normal value, followed by the development of a persistent deficit on the seventh day, and did not reach the control level until the end of the experiment (Table 1). The concentration of aldosterone in the adrenal tissue on the first day after deltamethrin administration was close to the normal level; on the third day it decreased sharply and after 7 days increased again, but remained below the control level. Thirty days later, aldosterone deficiency was pronounced in adrenal tissue.

The change in the concentration of hormones in the blood serum and adrenal tissue was accompanied by an increase in the mass of AG in the first 3 days of the experiment, followed by its decrease. At this period, during the histological examination, we found that edema of the organ parenchyma and the blood capillaries were overfilled. The glomerular and fascicular zones were enlarged. Cells of the glomerular zone were a rounded shape; the contours of the cells were distinctly expressed. The cells of the fascicular zone were polygonal, large, with large rounded nuclei. Corticocytes of the reticular zone also contained the large rounded nuclei in which chromatin accumulations were distinctly expressed. A histochemical study revealed a large number of lipid droplets in the cytoplasm of the cells of the fascicular and glomerular zones. At the border of the cortex and the medulla of AG, mast cells were recorded, some of them in the degranulation stage. In subsequent periods of the experiment, the borders of the glomerular, and especially fascicular zones, narrowed, the size of the corticocytes decreased, and the lysed and pycnotic nuclei were found. The lipid content in the cells was reduced. The weight of AG was already sharply decreased 7 days after intoxication and had not reached the initial values at the end of the experiment. 
Table 1.

The dynamics of the concentration of hormones in the blood serum and adrenal tissue in rats after a single administration of deltamethrin at a dose of $17.4 \mathrm{mg} / \mathrm{kg}(1 / 5 \mathrm{LD} 50), \mathrm{Me}\left(Q_{1}-Q_{3}\right)$

\begin{tabular}{|c|c|c|c|c|c|c|c|c|}
\hline \multirow{3}{*}{ Group } & \multicolumn{2}{|c|}{ Progesterone } & \multicolumn{2}{|c|}{ DHEAS } & \multicolumn{2}{|c|}{ Corticosterone } & \multicolumn{2}{|c|}{ Aldosterone } \\
\hline & Serum & $\mathrm{AG}$ & Serum & $\mathrm{AG}$ & Serum & $\mathrm{AG}$ & Serum & $\mathrm{AG}$ \\
\hline & $\mathrm{ng} / \mathrm{ml}$ & $\mathrm{ng} / \mathrm{mg}$ tissue & $\mathrm{ng} / \mathrm{ml}$ & $\mathrm{ng} / \mathrm{mg}$ tissue & $\mathrm{nmol} / 1$ & $\mathrm{ng} / \mathrm{mg}$ tissue & $\mathrm{pg} / \mathrm{ml}$ & $\mathrm{ng} / \mathrm{mg}$ tissue \\
\hline \multicolumn{9}{|c|}{ Day 1} \\
\hline $\begin{array}{l}\text { Group } 1 \\
\mathrm{n}=10\end{array}$ & $\begin{array}{c}9.40 \\
(7.20-10.7)\end{array}$ & $\begin{array}{c}1.77 \\
(1.44-2.14)\end{array}$ & $\begin{array}{c}130 \\
(95.8-154)\end{array}$ & $\begin{array}{c}7.57 \\
(6.32-8.82)\end{array}$ & $\begin{array}{c}417 \\
(378-500)\end{array}$ & $\begin{array}{c}17.9 \\
(13.0-19.3)\end{array}$ & $\begin{array}{c}98.0 \\
(70.1-106)\end{array}$ & $\begin{array}{c}1.22 \\
(0.907-1.33)\end{array}$ \\
\hline $\begin{array}{l}\text { Group } 2 \\
\mathrm{n}=12\end{array}$ & $\begin{array}{c}10.0 \\
(6.55-11.8) \\
\text { NS }\end{array}$ & $\begin{array}{c}1.05 \\
(0.687-1.24) \\
P=0.0031\end{array}$ & $\begin{array}{c}190 \\
(132-198) \\
P=0.0373\end{array}$ & $\begin{array}{c}5.59 \\
(4.63-6.17) \\
P=0.0112\end{array}$ & $\begin{array}{c}544 \\
(487-662) \\
P=0.0043\end{array}$ & $\begin{array}{c}10.0 \\
(6.92-10.7) \\
P<0.0001\end{array}$ & $\begin{array}{c}158 \\
(128-169) \\
P<0.0001\end{array}$ & $\begin{array}{c}1.05 \\
(0.657-1.19) \\
\mathrm{NS}\end{array}$ \\
\hline \multicolumn{9}{|c|}{ Day 3} \\
\hline $\begin{array}{l}\text { Group } 3 \\
\mathrm{n}=10\end{array}$ & $\begin{array}{c}6.22 \\
(3.94-11.1) \\
\end{array}$ & $\begin{array}{c}1.71 \\
(1.27-1.86) \\
\end{array}$ & $\begin{array}{c}141 \\
(107-150) \\
\end{array}$ & $\begin{array}{c}8.42 \\
(6.64-9.50) \\
\end{array}$ & $\begin{array}{c}395 \\
(366-470) \\
\end{array}$ & $\begin{array}{c}16.4 \\
(13.6-17.8) \\
\end{array}$ & $\begin{array}{c}77.7 \\
(73.1-95.1) \\
\end{array}$ & $\begin{array}{c}1.26 \\
(1.03-1.53) \\
\end{array}$ \\
\hline $\begin{array}{l}\text { Group } 4 \\
n=12\end{array}$ & $\begin{array}{c}3.17 \\
(2.15-7.26) \\
\mathrm{NS}\end{array}$ & $\begin{array}{c}0.741 \\
(0.384-0.806) \\
P<0.0001\end{array}$ & $\begin{array}{c}116 \\
(101-149) \\
\text { NS }\end{array}$ & $\begin{array}{c}7.17 \\
(6.09-8.01) \\
\text { NS }\end{array}$ & $\begin{array}{c}524 \\
(414-600) \\
P=0.0271\end{array}$ & $\begin{array}{c}19.3 \\
(14.8-20.8) \\
\text { NS }\end{array}$ & $\begin{array}{c}99.0 \\
(76.1-118) \\
\text { NS }\end{array}$ & $\begin{array}{c}0.400 \\
(0.274-0.575) \\
P<0.0001\end{array}$ \\
\hline \multicolumn{9}{|c|}{ Day 7} \\
\hline $\begin{array}{l}\text { Group } 5 \\
n=10\end{array}$ & $\begin{array}{c}8.55 \\
(6.37-10.7)\end{array}$ & $\begin{array}{c}1.53 \\
(1.20-2.22)\end{array}$ & $\begin{array}{c}101 \\
(80.4-139)\end{array}$ & $\begin{array}{c}7.23 \\
(5.90-8.90)\end{array}$ & $\begin{array}{c}428 \\
(368-502)\end{array}$ & $\begin{array}{c}17.5 \\
(11.5-19.3)\end{array}$ & $\begin{array}{c}85.7 \\
(76.8-105)\end{array}$ & $\begin{array}{c}1.05 \\
(0.916-1.36)\end{array}$ \\
\hline $\begin{array}{l}\text { Group } 6 \\
\mathrm{n}=12\end{array}$ & $\begin{array}{c}3.71 \\
(1.92-4.67) \\
P<0.0001\end{array}$ & $\begin{array}{c}0.633 \\
(0.431-1.45) \\
P=0.0079\end{array}$ & $\begin{array}{c}96.0 \\
(84.2-118) \\
\text { NS } \\
\end{array}$ & $\begin{array}{c}7.81 \\
(5.25-7.91) \\
\mathrm{NS}\end{array}$ & $\begin{array}{c}425 \\
(338-471) \\
\text { NS } \\
\end{array}$ & $\begin{array}{c}7.35 \\
(6.41-14.1) \\
P=0.0092\end{array}$ & $\begin{array}{c}62.7 \\
(48.7-81.6) \\
P=0.0077\end{array}$ & $\begin{array}{c}0.877 \\
(0.766-1.29) \\
\mathrm{NS}\end{array}$ \\
\hline \multicolumn{9}{|c|}{ Day 30} \\
\hline $\begin{array}{l}\text { Group } 7 \\
\mathrm{n}=10\end{array}$ & $\begin{array}{c}7.67 \\
(5.21-11.8) \\
\end{array}$ & $\begin{array}{c}1.63 \\
(1.21-1.82) \\
\end{array}$ & $\begin{array}{c}135 \\
(101-144) \\
\end{array}$ & $\begin{array}{c}6.77 \\
(5.58-8.49) \\
\end{array}$ & $\begin{array}{c}466 \\
(304-496) \\
\end{array}$ & $\begin{array}{c}15.3 \\
(11.1-21.1) \\
\end{array}$ & $\begin{array}{c}88.0 \\
(78.5-125) \\
\end{array}$ & $\begin{array}{c}1.16 \\
(1.12-1.38)\end{array}$ \\
\hline $\begin{array}{l}\text { Group } 8 \\
\mathrm{n}=12\end{array}$ & $\begin{array}{c}3.21 \\
(2.14-6.16) \\
P=0.0128\end{array}$ & $\begin{array}{c}0.809 \\
(0.719-1.48) \\
P=0.0157\end{array}$ & $\begin{array}{c}123 \\
(96.0-137) \\
\text { NS }\end{array}$ & $\begin{array}{c}6.19 \\
(4.68-6.45) \\
\text { NS }\end{array}$ & $\begin{array}{c}295 \\
(221-348) \\
P=0.0152\end{array}$ & $\begin{array}{c}10.9 \\
(5.41-13.1) \\
P=0.0227\end{array}$ & $\begin{array}{c}49.5 \\
(40.3-86.6) \\
P=0.0157\end{array}$ & $\begin{array}{c}0.814 \\
(0.513-0.876) \\
P<0.0001\end{array}$ \\
\hline
\end{tabular}

\section{Discussion}

Our study allowed us to evaluate the morphological changes and functional activity of AG after a single administration of deltamethrin in a toxic dose. During the period of observation, we found a decrease in BW of animals after intoxication, and an increase in adrenal mass during the initial period of the experiment, followed by a decrease. With this regularity, not only the absolute but also the relative mass of the adrenal glands changed, as evidenced by their mass indices.

During the first day after deltamethrin administration, an active secretion of DHEAS, corticosterone and aldosterone into the blood was found, which was accompanied by a decrease in the content of these hormones in adrenal tissue. This indicates the development of the stage of anxiety under stress, as a result of which the internal reserves of the organism are mobilized. This confirms the increase in the mass of AG and its functional zones responsible for the synthesis of steroid hormones. Reducing the amount of lipids in corticocytes 3 days after intoxication is associated with activation of the process of corticosteroid formation after exposure to deltamethrin. Depletion of lipid stocks in the fascicular zone of the adrenal glands characterizes the state of stress in animals ${ }^{(22)}$ and is observed at increased secretion of ACTH. ${ }^{(23)}$
With the passage of time, the biosynthesis of DHEAS was recovered against the backdrop of the development of a deficit of corticosterone and aldosterone. A low level of progesterone in rats with acute intoxication with deltamethrin was observed throughout the study period. This could be one of the reasons for lowering the synthesis and secretion of corticosterone and aldosterone, since progesterone is an intermediate metabolite in the biosynthesis of these hormones. In addition, a deficit of corticosteroids may be due to other causes. First, in conditions of acute poisoning with deltamethrin due to liver damage, the synthesis rate and the transport of cholesterol, which is the substrate for the synthesis of all steroid hormones, can be disrupted. The hepatotoxic effect of synthetic pyrethroids is presented in the studies of a number of authors. ${ }^{(14,15)}$ Secondly, the deltamethrin intoxication contributes to the enhancement of free radical processes against the background of a decrease in the reserves of the antioxidant system, ${ }^{(16,17,24)}$ which is an inhibitory factor for steroidogenesis enzymes. ${ }^{(25)}$ Thirdly, there may be absent the stimulus from the pituitary and hypothalamus. The level of ACTH in the long-term followup was close to the control values, although a deficiency of corticosterone should cause an increase in ACTH secretion by the feedback principle.

Thus, our results of the study allow us to conclude that a 
single administration of deltamethrin to rats at a dose of 17.4 $\mathrm{mg} / \mathrm{kg}$ (1/5 LD50) causes morphofunctional changes in AG, characterizing the development of the stress response. One day after intoxication, a large amount of $\mathrm{ACTH}$, corticosterone and other adrenal hormones are released into the blood, and the absolute and relative mass of AG increases. Over time, the index of adrenal weight decreases in animals, which is accompanied by a decrease in the level of corticosteroids. The death of animals during the experiment was not observed. However, the studied indicators did not recover to the level of control values within a month, which indicates the possibility of developing post-toxic complications.

\section{Acknowledgements}

We would like to thank Vladimir D. Conway for technical assistance.

\section{Competing interests}

The authors declare that they have no competing interests.

\section{References}

1. Soderlund DM. Molecular Mechanisms of Pyrethroid Insecticide Neurotoxicity: Recent Advances. Arch Toxicol. 2012;86(2):165-81. doi: 10.1007/s00204-011-0726-x.

2. Tyler CR, Beresford N, van der Woning M, Sumpter JP, Tchorpe K. Metabolism and environmental degradation of pyrethroid insecticides produce compounds with endocrine activities. Environ Toxicol Chem. 2000;19(4):801-9. doi: 10.1002/etc.5620190404.

3. Ji G, Xia Y, Gu A, Shi X, Long Y, Song L, et al. Effects of non-occupational environmental exposure to pyrethroids on semen quality and sperm DNA integrity in Chinese men. Reprod Toxicol. 2011;31(2):171-6. doi: 10.1016/j. reprotox.2010.10.005.

4. Kumar A, Bhaskar A, Chandra S, Sasmal D, Mukhopadhyay K, Sharma N. Mechanism of deltamethrin induced immunotoxicity: Current and future perspectives. Receptors Clin Investig. 2015;2(2):e578. doi: 10.14800/rci.578.

5. Skolarczyk J, Pekar J, Nieradko-Iwanicka B. Immune disorders induced by exposure to pyrethroid insecticides. Postepy Hig Med Dosw (Online). 2017;71(0):446-53.

6. Spencer CI, Kathryn HY, Borg JJ, Hancox JC, Kozlowski RZ. Actions of pyrethroid insecticides on sodium currents, action potentials, and contractile rhythm in isolated mammalian ventricular myocytes and perfused hearts. J Pharmacol Exp Ther. 2001; 298(3):1067-82.

7. Bhaskar EM, Moorthy S, Ganeshwala G, Abraham G. Cardiac conduction disturbance due to prallethrin (pyrethroid) poisoning. J Med Toxicol. 2010;6(1):27-30. doi: 10.1007/ s13181-010-0032-7.

8. Ye M, Beach J, Martin JW, Senthilselvan A. Pesticide exposures and respiratory health in general populations. J Environ Sci (China). 2017;51:361-70. doi: 10.1016/j. jes.2016.11.012.

9. Spencer J, O’Malley M. Pyrethroid Illnesses in California,
1996-2002. Rev Environ Contam Toxicol. 2006;186:57-72. 10. Ding G, Bao Y. Revisiting pesticide exposure and children's health: focus on China. Sci Total Environ. 2014;472:289-95. doi: 10.1016/j.scitotenv.2013.11.067.

11. Vazquez PP, Mughari AR, Galera MM. Solid-phase microextraction (SPME) for the determination of pyrethroids in cucumber and watermelon using liquid chromatography combined with post-column photochemically induced fluorimetry derivatization and fluorescence detection. Anal Chim Acta. 2008;607(1):74-82. doi: 10.1016/j.aca.2007.11.027.

12. Reuters: Pyrethroids - Global Market Outlook (20172023). Available from: http://www.reuters.com/brandfeatures/ venture-capital $/$ article $?$ id $=12574$

13. PubChem: Deltamethrin. Available from: https://pubchem. ncbi.nlm.nih.gov/compound/deltamethrin\#section=Top

14. Chargui I, Grissa I, Bensassi F, Hrira MY, Haouem S, Haouas Z, et al. Oxidative stress, biochemical and histopathological alterations in the liver and kidney of female rats exposed to low doses of deltamethrin (DM): a molecular assessment. Biomed Environ Sci. 2012;25(6):672-83. doi: 10.3967/0895-3988.2012.06.009.

15. Sharma P, Singh R, Jan M. Dose-dependent effect of deltamethrin in testis, liver, and kidney of Wistar rats. Toxicol. Int. 2014;21(2):131-9. doi: 10.4103/0971-6580.139789.

16. Chigrinski EA, Conway VD, Gerunova LK, Gerunov TV. Glutathione-related enzyme activity in rats' testes and epididymis at an acute intoxication with a synthetic pyrethroid deltamethrin. Int J Pharma Bio Sci. 2015;6(4):B340-4.

17. Issam C, Samir H, Zohra H, Monia Z, Hassen BC. Toxic responses to deltamethrin (DM) low doses on gonads, sex hormones and lipoperoxidation in male rats following subcutaneous treatments. J Toxicol Sci. 2009;34(6):663-70.

18. Tsigos C, Chrousos GP. Hypothalamic-pituitary-adrenal axis, neuroendocrine factors and stress. J Psychosom Res. 2002;53(4):865-71.

19. Charmandari E, Tsigos C, Chrousos G. Endocrinology of the stress response. Annu Rev Physiol. 2005;67:259-84. doi: 10.1146/annurev.physiol.67.040403.120816.

20. Nicolaides NC, Kyratzi E, Lamprokostopoulou A, Chrousos GP, Charmandari E. Stress, the stress system and the role of glucocorticoids. Neuroimmunomodulation. 2015;22(12):6-19. doi: 10.1159/000362736.

21. Nussey S, Whitehead S. Endocrinology: An Integrated Approach. Oxford: BIOS Scientific Publishers; 2001.

22. Sharawy M, Dirksen T, Chaffin J. Increase in free cholesterol content of the adrenal cortex after stress: radioautographic and biochemical study. Am J Anat. 1979;156(4):567-75. doi: 10.1002/aja.1001560409.

23. Pudney J, Sweet PR, Vinson GP, Whitehouse BJ. Morphological correlates of hormone secretion in the rat adrenal cortex and the role of filopodia. Anat Rec. 1981;201(3):537-51. doi: 10.1002/ar.1092010310.

24. Nieradko-Iwanicka B, Borzecki A. How Deltamethrin Produces Oxidative Stress in Liver and Kidney. Pol J Environ Stud. 2016;25(3):1367-71. doi: 10.15244/pjoes/61818.

25. Prasad R, Kowalczyk JC, Meimaridou E, Storr HL, Metherell LA. Oxidative stress and adrenocortical insufficiency. J Endocrinol. 2014;221(3):R63-R73. doi: 10.1530/JOE-13-0346. 